\title{
Reviews
}

\section{The Last Yankee by Arthur Miller}

Arthur Miller's latest play, The Last Yankee, has transferred to the Duke of York theatre from the Young Vic where it played to full houses every night. It is his shortest piece to date, lasting just 80 minutes without interval. The language is simple, the action sparse, and the set minimalist as is the cast who number two married couples and a sleeping girl. She lies quietly on the stage hospital bed throughout the final two thirds of the play that is cut into three acts.

Act 1 is the conversation between visiting husbands, Leroy Hamilton and John Frick, who starts by commenting on the fineness of the parking lot. Act 2 is the meeting of Leroy and his wife Patricia and Act 3 brings both couples together in the hospital room where the sleeping girl lies in her mysterious limbo between presence and absence.

You see, Arthur Miller is a sly old bird. At 77, the playwright knows that less is more. What appears without clutter and complication is hiding chaos and turmoil underneath. Thus, the hospital is a psychiatric hospital. The illness is depression. The setting is suburban middle America. And Act after Act follows a pattern of politely composed beginnings careering helplessly into disaster and then picking back up again for more.

Leroy Hamilton is Miller's voice and perhaps his hero. Descendant of one of the Founding Fathers, from a great and powerful Yankee family, he has abandoned the privilege that society would love to bestow on him and lives life as a carpenter unable to charge enough for his labour, and unwilling to wear the overalls of the trade. Frick, an all-American businessman, respects the college clothes and 'royal' descent of Leroy, and assumes these mean certain things as certain things do. A common view, a common tax-bracket. When Leroy assaults Frick's assumptions about his clothing, Miller is really beginning his assault on the American view much as he had done in 1950, with An Enemy of the People and later with The Crucible; 40 years on Leroy can provide a clear and undisguised voice for Miller to speak out against the confusion that exists between money, power and human value in modern America.

In this context, the depressive illness of the two women is portrayed as evidence of how self-worth can lose all chance of expression. And although Patricia has a family history of two brothers committing suicide and 15 years on antidepressants, we are asked to believe that a change of attitude and a strong sense of self-belief are really what is needed. In an

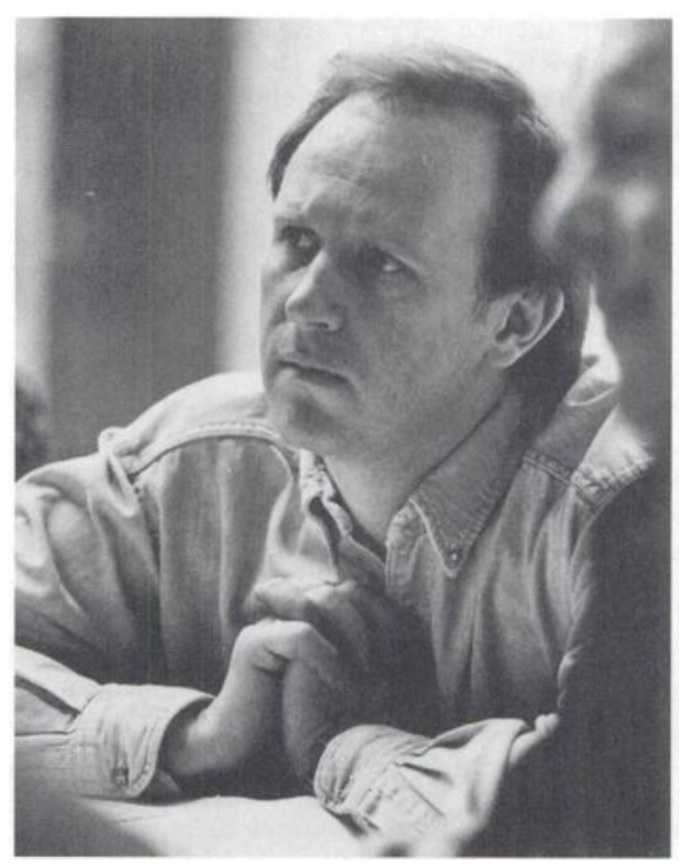

Peter Davidson as Leroy in rehearsal for 'The Last Yankee'. (Young Vic. Photograph by Alastair Muir).

otherwise marvellously evocative piece, Miller is infuriatingly naive to deal with depression except as the inevitable result of a morally bankrupt society. The audience left with their trust in more fresh air and strawberries, and the view that mental illness is a failure of individuals to make more of their lot (doctors and pills are conspicuously absent).

In a play about failure and disappointment each character gradually exposes failure and disappointment in themselves, alongside failure and disappointment in others, emerging as a stubbornly repetitive search for meaning that shall never be found convincingly. The upbeat ending is therefore fragile, as is Patricia's prognosis. The production, on the other hand, is immensely strong; stark and chillingly beautiful sets made surreal with frosted glass stage, new music and a limitless sky of moving clouds overhead. Like the play at first, deceptively serene.

Research Registrar

KATHRYN ABEL

The Institute of Psychiatry

London SE5 8AF 